\title{
Small Ruminant Community Breeding Program in Indonesia
}

\section{(Program Pemuliaan Berbasis Ternak Rakyat untuk Ruminansia Kecil di Indonesia)}

\author{
Bess Tiesnamurti ${ }^{1}$, SE Sinulingga ${ }^{2}$ and RM Gatenby ${ }^{3}$ \\ ${ }^{1}$ Indonesian Centre for Animal Research and Development \\ ${ }^{2}$ Indonesian Goat Research Institute, Galang, North Sumatera \\ ${ }^{3}$ Formerly Small Ruminant Collaborative Research Project, United Kingdom \\ Corresponding author: besstiesnamurti@pertanian.go.id
}

(Received 18 May 2020 - Revised 2 September 2020 - Accepted 5 September 2020)

\begin{abstract}
This paper outlines the principles of community breeding programs, reviews similar programs that have been conducted in Indonesia, as well as proposing improvements. Community breeding programs (CBP) are a method for genetic improvement of livestock, with voluntary participation of farmers, using animals belonging to the farmers, by defining breeding objectives and selection criteria or traits, selecting the best males of the group, performance testing and distributing males to the farmers. Farmers have the ownership of the program and contribute to the sustainability of the program, marketability of the products according the needs of the farmers, as well as strengthening farmers institutions. There are breeding scehemes of one tier, two tier and three tier that can be implemented to achieve the goals of genetic improvement. Several CBP has been carried out scatteredly, however improvements have to be made such as by long term financial support, strong commitment from breeders, mentoring by academias, data management and analysis as well as economic assessment. Therefore, a more masive and sustainable CBP should be conducted to improve the genetic quality of sheep and goat in Indonesia.
\end{abstract}

Key words: Community breeding programs, breeding strategy, small ruminants, selection criteria

\begin{abstract}
ABSTRAK
Makalah ini menyampaikan prinsip utama pelaksanaan CBP, mengevaluasi program serupa yang pernah dilaksanakan di Indonesia serta usulan perbaikan pelaksanannya. Program pemuliaan berbasis ternak milik rakyat (CBP) merupakan metode perbaikan mutu genetik ternak, dengan partisipasi aktif para peternak, mempergunakan ternak milik masyarakat, dengan menentukan tujuan pelaksanaan pemuliaan dan kriteria pelaksanaan seleksi maupun sifat produksi yang diinginkan, menentukan pejantan terbaik dalam kelompok tersebut, pelaksanaan uji performans serta distribusi pejantan terbaik kepada peternak anggota program ini. Peternak mempunyai kepemilikan terhadap program pemuliaan ini dan berperan dalam keberlanjutannya, akses memasarkan produk dihasilkan dari program ini sesuai dengan kebutuhan peternak, begitu pula dengan memperkuat kelembagaan peternak terkait. Terdapat tiga skema pemuliaan yaitu skema satu strata, skema dua srata dan skema tiga srata. Beberapa kegiatan CBP pernah dilaksanakan dan diperlukan penyempuranaan antara lain dukungan pendanaan, komitmen dari peternak, pendampingan dari kalangan akademia, data management dan analisa serta penilaian sosial ekonomi. Oleh karena itu diusulkan untuk membangun program pemuliaan berbasis ternak rakyat untuk ruminansia kecil.
\end{abstract}

Kata kunci: Pengembangan kawasan bibit, strategi pemuliaan, ruminansia kecil, kriteria seleksi

\section{INTRODUCTION}

Small ruminants are widely kept by small holder farmers and are distributed almost throughout the country. The animals are used widely for meat, fertilizer, leather and a small percentage are kept for milk and wool producer. The total populations of sheep and goats are about 17.8 and 18.9 million head, respectively (Directorate General of Livestock and Animal Health 2019). The top five provinces with the highest sheep population are in East Java, Central Java, West Java, South Sulawesi and North Sumatera. Meanwhile, the outstanding goat population can be found in North Sumatera, Lampung, West Java, East Java and South Sulawesi province. The majority of small ruminants are still managed traditionally, grazed in natural pastures where available, such as in West Nusa Tenggara, East Nusa Tenggara, Aceh and North Sumatera. In areas where communal grazing lands are not exist, the animals are kept indoors and feeds are provided by the cut and carry system. The range of sheep and goats ownership is 1-7 head/household, although there are also traditional farmers who keep up to 150 head in certain areas where grazing is not a problem. Nonetheless, there are also fattening business of small ruminants considered as large herds $(1,500$ 
head or so), with daily slaughter to be around 10-20 head. Demand for mutton is quite good, as presented from the statistical report of Directorate General of Livestock and Animal Health (2019) with the number of sheep and goats slaughtered estimated around 3.2 million head/year.

Important considerations in maintaining the genetic diversity of livestock at farm level include of mating management, selection and distribution of best males, replacement of females for the base population, culling management as well as animal slaughtering to produce meat. Therefore, the principle of conservation while utilizing of sheep and goats is a must for the country. Small ruminant genetic improvement at the farmers' level by using local genetic resources has to be sustainable for food security purposes.

So far, the genetic improvement of small ruminant has been conducted by government institutions, as well as the private sectors that have interest in it. The institutions responsible for such activities are Ministry of Agriculture, conducted by Agency for Agriculture Research and Development, i.e. Research Institute for Animal Production and Research Institute for Goats. Compass Agrinak has been declared as new composite breed of sheep after long research which started at the beginning of SR-CRSP Project in 1985. There are also Institutes for Animal Breeding at Plaihari and Baturaden, belong to the Directorate General of Livestock and Animal Health that focus on breeding of meat and dairy goats. Livestock and Animal Health Services in several provinces also have stations for small ruminant multiplication, such as Garut Sukawargi and Jember Garahan. These government institutions produce genetically superior animals which are distributed to farmers, to improve the genetic merit of sheep and goats belong to the farmers. Not to be forgotten, the important roles of farmers and other individuals who have interest to genetically improve their animals such as farmers groups and/or farmers associations. There are sheep and goat farmer association in the country that take important roles on small ruminant genetic improvement.

Open nucleus and close nucleus breeding program are the common strategies used to improve the genetic of livestock (Mueller \& James 1984; Nicoll 1990). Ideally, there should be an elite group of animal, then followed by the second layer as multiplicator of the breed then followed by the final user.

Community based breeding programs (CBP) are not new in Indonesia and have been practiced for years. The economic value of sheep and goats is the main driving force for farmers to breed for better quality and productivity. Besides daily consumption of mutton, another hit market is sacrifice at Idhul Adha. Animal contests at district, provincial or even national levels are another reason for farmers to breed the animals.
The national program on genetic improvement of livestock at farm level recognizes village breeding programs, and has been run since 2005. Haile et al. (2011) stated that CBP can improve productivity and income of small-scale resource poor sheep producers in Ethiopia by providing access to improved animals that respond to improve feeding and management, facilitating the targeting of specific market opportunities. Not only that, expected outputs from $\mathrm{CBP}$ are a) breeding goals defined in a participatory manner by farmers and at least one breeding program established per breed, b) methodological framework for the development of CBP for smallholder producers, including institutional arrangements, c) impact assessment of the breeding system at individual, flock, community and national levels, d) assessment on a national basis, of the characteristics of the breeds managed by breeding programs and e) better understanding of the constraints to market access by sheep keepers.

The aim of this paper is to explain the principles of community breeding programs, similar programs that have been conducted in Indonesia as well proposed improvements.

\section{PRINCIPLES OF COMMUNITY BREEDING PROGRAMS (CBP)}

These programs require act ive involvement and sustainability of many stakeholders, considering that target of genetic improvement depends significantly on heritability, the numbers of population, male selection as well as selection intensity. The program also requires continuous data collection, storage in data base and analysing to obtain breeding value, to decide which males will be used for mating. Males not required for breeding have to be culled. This is a relatively long process which takes five generations or approximately 15 years depned on the species of the livestock and the trait being measured.

Community based breeding program was created to improve the genetic merit, to avoid or to reduce inbreeding as well as to disseminate genetic superiority of animals. Considering the level of the breeding program, there are at at least three types such as 1) one tier breeding program consist of a few breeding males with many breeding females. In this system, the male and female progenies will be selected and replaced the parental stock; 2) two tier breeding program consists of nucleus flock and commercial producers, to improve their productivity with the different genetic quality of about two generations; 3 ) three tier breeding program consists of nucleus flock with 826 head of ewes, the multipliers flock of 7000 head of ewes and lastly the commercial producers with 180.000 ewes (Santos et al. 2017). The dissemination of the breeding rams either 
from nucleus to multipliers flock or from multipliers to commercial flocks was proposed to improve the sheep productivity in that tier. The nucleus flock itself, can be as central nucleus (be used alot for pigs, poultry and some dairy) and disperse nucleus (for sheep and cattle). In term of gen flow, the nucleus of breeding schemes can be as closed nucleus system (replacement animals for nucleus only from nucleus, selection only permanently effective in nucleus, however nucleus objectives impacted on whole scheme) or open nucleus system (replacement animals can be from nucleus as well as from base flock, selecting from base flock requires meaasurement in base and more genetic improvement compared to closed scheme). Santos et al. (2017) reported a three layer breeding system in New Zealand sheep industry with 826 breeding ewes in nucleus, 7.000 head in multiplier and 180.000 breeding ewes at commercial flock. The breeding rams at the nucleus, multiplier and commercial was 10; 70 and 1800 head for nucleus, multiplier and commercial flocks respectively. The study was aimed to assess the potential benefit that may arise from introducing performance recording, parentage testing and genomic selection to the multiplier tier of a multi tier breeding scheme. The report showed that strong genetic correlation was resulted between ewe mature weight and weaning weight (0.55), weaning weight and carcass weight $(0.75)$, body condition score and ewe mature mature weight $(0.50)$ as well as between carcass weight and ewe weight (0.75). By utilizing DNA parentage of the ewes, the genetic response can be achieved faster compared to conventional method. The study also strenghten by Mrode et al. (2018) in utilization of moleculer markers in parentage identification the animals in the study, especially in using animals at the CBP activities that do not have recording data. The individual identification will accelarate the genetic evaluation by giving more accurate estimates of relationships between individuals, genetic diversity and also the inbreeding coefficient.

In designing the CBP, there are several points to be considered such as trait measurement (the genetic trait, animal involmenet male and females, progeny testing, the tier involvement such as tier and commercial, as well as the utilization of genetic markers), estimation of breeding values (phenotypic evaluation, pedigree arrangement, using BLUP also genetic markers) and the utilization of reproductive technology such as artificial insemination (AI) , multiple ovulation and embryo transfer (MOET), jouvenille in vitro embryo transfer (JIVET) and cloning, as reported by Granleese et al. (2015). König et al. (2016) reporting the participatory definition of the breeding objectives for sheep breeds in Kenya, using local breeds (Red Maasai, Dorper and its crosses) kept at different environment conditions (harsh and adequate). The study showed that location of the study, the use of sheep breed and the ranking of animals had significant influence to body weight, body length, milk yield and the price of animal. Farmers at adequate condition preferred to have sheep with higher growth traits and thus tending to have to have better price, considering that enough feed resources. However, ini harsh area, farmers did not mind to have lower growth rate as long as the number animals available and can be kept by farmers. This situation means that CBP can be conducted at different environment situation which is suitable to farmers preferences.

However, governments in developing countries are not able to conduct genetic improvement at the farm level due to limited budgets, little commitment of farmers and minimal infrastructure. Therefore, a model of genetic improvement at farm level known as community breeding program is introduced. The strategy has to be designed according to the need of the farmers, views, decisions and active participation from all members of the program. From the very beginning of the program, starting with planning, the success of the program is very much affected by active participation of the farmers in order to decide breeding objectives, the availability of infrastructure, as well as the ownership of the farmers (Haile et al. 2011). Community Breeding Programs are an avenue for genetic improvement by involving local farmers and using their animals.

Table 1. Breeding Project that Implement CBP

\begin{tabular}{lcccl}
\hline \hline Trait & Breed & $\begin{array}{c}\text { Number of Animal } \\
\text { (head) }\end{array}$ & $\begin{array}{c}\text { Breeding Scheme/Expected } \\
\text { genetic gain }\end{array}$ & Reference \\
\hline Prolificacy & Morada Nova hair sheep & 252 & Two tier & Lacerdaa et al. (2016) \\
Growth rate & Black Bengal goat & 1080 & Two tier $/ 0.87$ & Abegaz et al. (2014) \\
Growth rate & Abergelle goat & 1246 & Two tier & Birhanie et al. (2018) \\
Growth rate & Gumpz sheep & 14.057 & Two tier/0.336 kg year ${ }^{-1}$ & Dagnew et al. (2018) \\
Growth rate & Local sheep in the area & 180.000 & Multi tier/2-7\% year ${ }^{-1}$ & Santos et al. (2015) \\
\hline
\end{tabular}


Before implementing CBP, there are several points to be considered (Haile et al. 2011), such as:

1. Selecting target breeds and communities. Several factors to be considered such as the breed that is most populous in the area, genetic diversity, type of breed, the support of research centre in the area and road access to the area. The choice of community selection is another important factor, and the decision to choose a certain community depends on factors such as market accessibility, time allocation of farmers for livestock rearing, relation with other projects, support from NGO and government, the numbers of animals in the area, and key person in the area.

2. Characterization of target sites and breeds. To decide the target site, one has to consider the description of production system in term of roles of livestock in the area, economic value of the production system and current breeding practices. Phenotypic and molecular characterization are another very important factor that significantly support the success of the project.

3. Defining breeding objectives. This has strong correlation with market demand, and affects a long term economic benefit, therefore needs to be defined accurately. The views of farmers, the condition of the animals and market agent along the value chain have to be reviewed accordingly.

4. Assessment of alternative breeding plans. Every situation requires different breeding plans, hence suitable plans clearly considered regarding the number of tiers, sexes in the selection group and gene transfer from one group to another.

5. Developing breeding structure. In general, there are two models of the structure i.e. open and closed nucleus schemes. Each scheme has its own advantages and deciding which scheme is most appropriate requires judgement of the community, market and breed. The main considerations are obtaining optimum production of the animals, selection of the best animals belonging to the farmers and utilizing these for the community.

There are several traits of small ruminants that can be used when implementing CBP (Haile et al. 2011) and in Indonesia only wool production cannot be obtained. Several CBP projects have been conducted in various countries with positive results. One study reported that molecular markers can be very useful and can speed up the output of the project. Lacerdaa et al. (2016) stated that sheep on the community-based breeding program for Morada Nova hair sheep showed a high allelic diversity for the $\mathrm{Fec}^{\mathrm{GE}}$ allele (GDF9 gene), which is responsible for litter size. The identification of this allele using 252 head in young rams on performance tests may contribute to increased litter size, a trait that can influence profitability. If litter size can be managed properly, the number of lambs weaned and the body weight of lambs at weaning influence profitability. The number of lambs weaned significantly affected total weaning weight. If we can identify the rams with high prolificacy, the distribution of selected rams with high prolificacy will increase the number of lambs born and weaned, therefore will generate more income for the farmers. By exploiting the advantages of molecular marker, farmers can prepare the management practices required for maintaining sheep with high prolificacy to achieve certain production level.

Dossa et al. (2015) reported a study of breeding practices of sheep and goat kept by small holder farmers involving 301 head of sheep and 306 head of goats in West Africa. It showed that farmers had low breeding practices such as 1) castration, which means that degree of inbreeding could be higher due to unexpected mating among lambs to the dams, 2) lack of breeding records, which in turn will result on minimum information regarding their production information of the animals and 3) selection of replacements came from within flock, represents the high risk of inbreeding. In other words, the succesfull of CBP implementation rely largely on the commitment and partisipatory of the farmers. Farmers' preferences on certain traits of sheep will decide their participatory before joining a community breeding program (Duguma et al. 2011) This study reported a survey cocnducted on four breeds of local sheep Afar, Bonga, Horro and Menz using 60 household with a total of 240 ewe in each breed. Among the trait measured in rams, animal size, coat color, tail size, horn presence and libido were significantly affected in most of the breed, unless horn presence in horro sheep and tail size in Menz breed of sheep. Most of farmers showed significant influenced on the size, coat color, tail size, lambing interval, twinning rate and mothering ability. A significant influence traits for ewes include of milk production, body size, coat color and tail size, lambing interval, twinning rate and mothering ability, but not for tail size and coat color. This result is very important in designing the $\mathrm{CBP}$ to efficiently run in several generation.

Not to be forgotten, the study of Lamuno et al. (2018), who reported an important framework evaluation of the community based livestock breeding program with the purpose to monitor and evaluate the on going activities of CBP, to identify challenges and improperity during the execution of the program. Those activities are aimed as a guide for funding bodies to measure socio economis impact in the livelihoods of the farmers in order to decide if the program's goal have been achieved. The most important criterias on evaluation are divided into three categories, 1) 
monitoring implementation of the genetic improvement at farmers or herd level and also the changes at the houshold level and the communit, 2) evaluating CBP implementation based on organizational and technical criteria, and 3) evaluating the the impact of assess improvement in livelihoods of the farmers and the effect on the environment.

Table 2. Genetic traits and data availability

\begin{tabular}{|c|c|}
\hline Breeding objective & Traits recorded \\
\hline \multirow[t]{4}{*}{ Body size } & Birth weight \\
\hline & Three month weight \\
\hline & Six month weight \\
\hline & Yearling weight \\
\hline Lamb survival & Proportion of lambs weaned /ewe \\
\hline Twinning rate & $\begin{array}{l}\text { Numbers of lambs } \\
\text { born/ewe/lambing }\end{array}$ \\
\hline Milk yield & Test day milk yield (per month) \\
\hline Wool yield & Greasy fleece weight (yearling) \\
\hline
\end{tabular}

Source: Haile et al. (2011)

Lesson learn from CBP in Ethiopia, Mohammed et al. (2014) stated that management practices of culling inferior sheep, weaning at the right time, record keeping, castrating rams at the right age and provision of regular vaccination against diseases contribute to the success of sheep productivity. These activities have to be conducted by farmers and/or the extension service, therefore training can be done for farmers to improve management practices to enhance flock productivity. The indigenous sheep in the study areas were small in size $(25 \mathrm{~kg})$ so achieving a market weight of $30 \mathrm{~kg}$ is not easy. Therefore, careful cross breeding with larger indigenous sheep types should be considered where this long term strategy is required for better productivity. Farmers prefer to have qualitative traits like coat color, type and pattern in choosing animals, so it is also important to determine the economic value for such traits. In order to minimize the failure of breed improvement programs it is important to involve farmers when considering the existing breeding practices, management systems and trait preferences of the community and the multipurpose roles of targeted animals. Farmers are the main player of CBP, and prefer to improvement that require minimum cost of technology innovation however with such considerable outcome.

CBP run in Mexico using dairy goats, mention problems encountered during initial activities, at the end, farmers realize that breeding program make them less dependent to others in term of breed availability (both for Saanen and Anglo Nubian). Wurzinger et al. (2013) stated that the selection process of young breeding bucks based on their own growth performance and on milk performance is described as very important activity. Out of 64 farmers involve in the program, eight farmers are able to produce bucks to be used for mating of does in the study. The bucks selection were based on dams milk production (202-249 kg/lactation), total days milk (126-168 days) and kids daily gain (40$168 \mathrm{gram} / \mathrm{head} /$ day). The sustainability of a breeding program can only be ensured when there is a long-term commitment from researchers and extension services to collaborate with farmers and support them in the decision-making process. Not only that, the ownership of the project was created by handing-over many responsibilities and decision mechanisms to them and researchers played the role as facilitators. Farmers were open-minded, creative in problem-solving and interested to participate in a community-based breeding program. To ensure that farmers develop ownership of the program, the management of the program has to be designed according to the level of expertise and willingness of farmers to cooperate. A communitybased breeding program can work, but needs some technical support to get started and a continuous follow-up by technicians, although this can decrease over time.

Another work in Bangladesh reported by Bhuiyan et al. (2017), described community-based breeding as a farmer-participatory approach having common interest to conserve and improve their resources under lowinput production systems. Several breeding programs have been implemented on a limited scale mostly initiated and supported by academic and research institutions but with the government being involved. Some of these programs have shown promising results related to community production performance and farmers' livelihood improvements, particularly with Red Chittagong cattle, Black Bengal goats and Indigenous chickens. From these experiences, it is seen that farmers' participation is a very important element in those breeding programs. However, implementation of long-term and sustainable community-based breeding programs is a major challenge due mainly to short-term funding commitment from national and international donor agencies, lack of government commitment and rapid urbanization. The experiences gained from the previous CBPs indicate that selfsustained program operation is almost impossible under smallholder production systems where continuous technical and financial support services are needed. Institutional and infrastructural arrangements for functional breed society formation and for technical supports from local and national government, financial assurance at least for complementary services and farmers' participation as owners of the programs are all essential for successful implementation and sustainability of a breeding program in a wider scale. The nature of community based livestock breeding is 
not similar to other conventional breeding practices and therefore, there is a need to setup plans according to production environments and farmers' need in a bottom-top manner.

Ethiopia as one diverse country on animal genetic resources (Dagnew et al. 2018) reported genetic improvement using various models of genetic improvement advantaging Gumz sheep in Ethiopia. Selection based breeding schemes have the potential to provide resource-poor producers with access to improved animals that could ensure increased productivity of animals and contribute to reduced poverty. The study used two village-based and two central nucleus-based sheep breeding schemes, with the following scheme-1: a village-based breeding scheme with existing lambing, scheme-2: a village-based scheme with improved lambing, scheme-3: central nucleus-based scheme with 5\% nucleus size and scheme-4: central nucleus-based scheme with $10 \%$ nucleus size. The results showed that the annual genetic gains per year in 6-months weight $(\mathrm{kg})$ was about 0.16 in the village-based schemes, and 0.33 in the centralbased schemes. The annual genetic gain per year in number of lambs born per ewe bred ranged from 0.0017 to $0.0036 \%$ in both village and central nucleusbased schemes. The genetic gain in the proportion of lambs weaned per ewe was comparable across central nucleus-based scheme but little differed in villagebased schemes and ranged from 0.0015 to $0.0016 \%$. The Central nucleus-based schemes resulted in the highest genetic gain and economic efficiencies in all breeding objectives compared to village-based schemes. However, this scheme requires establishing a very large central nucleus flocks. Village-based schemes with estrous synchronization were a good option. The expected genetic gains and profits were higher as it promotes participation of farmers and achieving concentrated lambing which in turn increases selection intensity and genetic progress. This suggested the possibility for sustainable Gumz sheep improvement and conservation through village-based schemes and estrous synchronization.

By different breeding scheme offered, it is an opportunity for Indonesia to implement into their breeding program for several breeds of sheep and or goat. Considering the tier- 2 breeding scheme could be best fit in for the country situation.

\section{GENETIC IMPROVEMENT OF SMALL RUMINANT USING COMMUNITY BREEDING PROGRAMS IN INDONESIA}

\section{National policy for community breeding program}

During 1990-2000's era, the Directorate General of Livestock, Ministry of Agriculture tried to improve the livestock genetic quality belong to the farmers through the village breeding centre program for beef cattle, goats, sheep, poultry as well as pigs. The program was carried out by direct distribution of better livestock quality to the farmers through the formation of farmer groups and monitored their productivity by the local livestock service, universities and research institute. As time goes by, the livestock breeding centre and research institute started to produce new breed based on local genetic resources through selection and crossbreeding. With the decree of minister of agriculture, the local governments started to register local animal breed belong to the farmers at their districts and followed by designed the area for breed improvement.

The Ministry of Agriculture i.e. Directorate General of Livestock and Animal Health in Indonesia has registered 16 breeds of sheep and goats as local genetic resources. Those animals are registered by the local government and received a Decree of Ministry of Agriculture (Table 3). In line all those Ministry Decrees, the Ministry of Agriculture also published the Decree No. 64/Permentan/OT.140/11/2012 about regionalization for breeding stocks which was then followed by the Decree of Director General of Livestock and Animal Health Number: 1213/KPTS/F/12/2014 regarding the guidance of implementation for breeding of sheep and goats in selected districts of Kapahiyang, Tanggamus, Garut, Karang Asem, South West Maluku. Then, it was also strengthened by the Decree of DG of Livestock and Animal Number: 618/KPTS/PK.230/F/03/2016 (Directorate General of Livestock and Animal Health, 2016) regarding the guidance for implementation of sheep and goats breeding program in selected district of Kepahiangan, Tanggamus, Banjarnegara, Banyumas, Kulon Progo, South West Maluku, Kaligesing and Lumajang.

\section{Implementation of CBP}

With the decree, it is expected that the location could become identified for breed stock improvement. Among seven sheep breeds that have been registered, Banjarnegara and Garut districts have received breed stock development projects for Batur and Garut sheep, respectively. Additionally, six out of nine goat breeds have been selected for genetic improvement in eight provinces at ten districts (Table 3). Besides the location stated at the Minister Decree, there are breeding research with the main goal is releasing new breed of small ruminant that is conducted by universities and research institute. Compass Agrinak sheep, Bahtera Agrinak sheep, Sapera dairy goat are conducted at Indonesian Research Institute for Animal Production), Boerka Galaksi Agrinak goat is underwent research at 
the Indonesian Research Institute for Goat, whereas breeding of Saburai goat is conducted at the University of Lampung. The Livestock Breeding Centre at Baturaden (Central Java) and at Plaihari (South Kalimantan) provide Anglo Nubian and Etawa goat, respectively to improve the milk production of local dairy goat. Those breed stocks (considered as nucleus) are distributed to small holder farmers (as lower level tier) to improve their body weight or milk production. IAARD created a program called multipication unit (UPBS/UPBU) which aimed to reproduce breed stock resulted from breeding research that will be distributed to the farmers. The management of UPBU at IRIAP and IRIG was established to separate the multiplication of superior breed stocks from research activities. The genetic quality of sheep and goat in the multiplication center is as good as in the nucleus or slighty lower as the selection intensity practiced.

The Boerka Galaksi Agrinak goat has been released by Decree of Minister of Agriculture 08/KPTS/PK.040/M/1/2020 and has been distributed to 13 provinces (total of 759 head male and female, during 2011-2019) involving two multiplier (Bangka Belitung and West Nusa Tenggara Indonesian Assessment of Technology) and farmers group. The goat has average birth weight of $2,3 \mathrm{~kg}$ with mature body weight of $35 \mathrm{~kg}$ (at 12 months age) and adapted to several feed resources such as sago by products (Simanihuruk et al. 2018; oilpalm by products (Ginting et al. 2018) and even legume suplementation (Tarigan et al. 2018). The number of population at the nucleus in 2019 was 1073 head. Under grazing management at low altitude, the study showed that feed consumption and daily gain of grazing Boerka Galaksi Agrinak goat were higher compared to non grazing animals (Destomo et al. 2018). Unfortunately the data (body weight from birth to adult, reproduction performance etc) at farmers condition is not yet reported.

Compass Agrinak, new breed of sheep (released with Minister of Agriculture Decree No 1050/Kpts/SR.120/10/2014) has been distributed to seven provinces in Indonesia, involving farmers group to develop the sheep. Researcher at the Indonesian Institute of Animal Production (IRIAP) bred the sheep to have well adaptation in estate crop management, expecting to have resistance to internal parasite, well adapted to humid environment and less wool cover. At the nucleus in IRIAP, the total number of compas agrinak was 319 head (2019). In North Sumatra province, the sheep already been kept by small holder farmers to integrate with the estate crops and located at least in 9 districts out of 15 districts in the province.

Table 3. Regulations for Breed Registration and Location For Genetic Improvement

\begin{tabular}{|c|c|c|c|}
\hline Breed & Province & Decree on breed registration ${ }^{1)}$ & Location for CBP $(2015,2016)$ \\
\hline \multicolumn{4}{|l|}{ Sheep: } \\
\hline Batur & Central Java & 2916/KPTS/OT.140/6/2011 & Banjarnegara \\
\hline Sapudi & East Java & 2389/Kpts/LB.430/8/2012 & - \\
\hline Garut & West Java & 2914/Kpts/OT.140/6/2011 & Garut \\
\hline Kisar & Maluku & 2913/Kpts/OT.140/6/2011 & - \\
\hline Palu & West Sulawesi & 697/Kpts/PD.410/2/2013 & - \\
\hline Wonosobo & Central Java & 2915/Kpts/OT.140/6/2011 & - \\
\hline Priangan & West Java & 300/Kpts/S.R.120/5/2017 & - \\
\hline \multicolumn{4}{|l|}{ Goats : } \\
\hline Gembrong & Bali & 696/Kpts/PD.410/2/2013 & Karang Asem \\
\hline Kacang & All Province & 2840/Kpts/LB.430/8/2012 & - \\
\hline \multirow[t]{3}{*}{ Etawa cross } & All Province & 695/Kpts/PD.410/2/2013 & Kepahiang, Bengkulu \\
\hline & & & Banyumas, Central Java \\
\hline & & & Kulon Progo, Jogjakarta \\
\hline Marica & South Sulawesi & 580/Kpts/SR.120/4/2014 & - \\
\hline Lakor & Maluku & 2912/Kpts/OT.140/6/2011 & South West Maluku \\
\hline Kaligesing & Central Java & 2591/Kpts/PD.400/7/2010 & Purworejo \\
\hline Senduro & East Java & 1055/Kpts/SR.120/10/2014 & Lumajang \\
\hline Saburai & Lampung & 359/Kpts/PK.040/6/2015 & Tanggamus \\
\hline Kecobong & Central Java & 301/Kpts/SR.120/5/2017 & - \\
\hline
\end{tabular}

${ }^{1)}$ Decree: Ministry of Agriculture Decree; 2) CBP: Community Breeding Program 
The average birth weight was $2.2 \mathrm{~kg}$, the average weaning weight was $11.9 \mathrm{~kg}$, the average mature body weight was $33 \mathrm{~kg}$, the average litter size was 1,5 and dam productivity was $21.3 \mathrm{~kg}$. Priyanto \& Suradisastra (2018) reported the development of the compas agrinak sheep in Banten province (as lower tier) are able to encourage economic development of the districts and province. The initial number of sheep was 81 head (male and female at 1:10 comparison) and the number of progeny of the first lambing was 120 head. For several years, the number of lambs were gowing. The impact of innovation was to improve the traditional farming practices in the area, to make the area as field school for small ruminants managemnet practices, to make the area as a centre for sheep breed stocks and economically increase the farmers income by rearing compass agrinak sheep. Again, the continous observation of the newly bred sheep did not last long, mainly due to the limited budget al.located by the institute.

The crossing between saanen and ettawa goat was aimed to improve the milk production, and the breeding of the goat expected to be released as new breed in the near future. The goat performance at the nucleus (IRIAP) as reported by Anggraeni (2018) showed that the birth weight of sapera kids were $3.03 \pm 0.54 \mathrm{~kg}$ and $3.17 \pm 0.47 \mathrm{~kg}$ whereas the weaning weight was $10.57 \pm 1.7 \mathrm{~kg}$ and $9.54 \pm 1.7 \mathrm{~kg}$ for male and female, resepctively. The milk production of sapera goat at week 13 range from 45.31 to 64.4 liter (Anggraeni et al. 2020) with higher milk production of does at kidding age of 5-6 year. The total number of goat at the nucleus in 2019 was 175 head and since the breeding research are still going on, goat distribution to farmers (as lower tier) at four provinces are limited, therefore not many data available at the moment.

Likewise, the genetic improvement of etawah grade goats by cross breeding with Boer goat was carried out by researchers from the Faculty of Animal Husbandry, University of Lampung starting in 2004 where the Boerawa goat had spread well in Tanggamus Regency. Even now, there are still quite a number of breeders who breed and the Boerawa goat is an icon of the district. The funding for this activity comes from the Lampung University Animal Husbandry Unit, the Animal Husbandry Service of Lampung Province and Tanggamus District and participatory from the breeders and farners. The CBP was conducted at Tanggamus District, where the animals belong to the farmers. The performance of Saburai goat (Etawah crossed with Boer goats) has been reported by Adhianto et al. (2016) at two sub districts (Gisting and Sumberejo) of Tanggamus district using weaning weight, body weight at one year old, bobot and preweaning growth rate. With the information provided, male birth weight of saburai kids at two subdistricts was not significantily differ $(3.42 \pm 0.28$ vs $3.48 \pm 0.41 \mathrm{~kg}$ for Gisting and Sumberejo sub districts). Similar result also reported for the weaning weight which is $16.2 \pm 3.7$ vs $16.85 \pm 2.58 \mathrm{~kg}$ and yearling weight of $36.56 \pm 4.85 \mathrm{vs}$ $38.3 \pm 5.35 \mathrm{~kg}$, respectively for Gisting and Sumberejo sub districts. This results suggest that does that been used in this study was genetically similar to produce kids with good birth weight and weaning weight. Not only that, this two location provide enough feeds supply that support the growth rate of the kids until one year old. Female birth weight, weaning weight and yearling weight of kids from the study sites was $3.3 \pm 0.4$ vs $3.1 \pm 0.3 \mathrm{~kg} ; 16.1 \pm 3.4$ vs $14.9 \pm 3.7 \mathrm{~kg}$ and 37.2 vs $34.7 \pm 5.2 \mathrm{~kg}$ respectively for kids at Gisting and Sumberejo sub districts, respectively (Adhianto et al. 2017). The birth weight, weaning weight and yearling weight were not significantly different for kids from both sites means that farmers in those areas provide good management practice, enough feed supply for the goats as well as good genetic merit of the animals in the program.

The study at Tanggamus district was also supported by growth curve analysis of both sexes from birth until one year old, and resulted that males $(y=0,1634 \mathrm{x}+3,29 ; \mathrm{R} 2=1)$ grow faster than females $(y=0,1493 \mathrm{x}+3,25 ; \mathrm{R} 2=1)$ as a common phenomena (Adhianto et al. 2015). Both growth curve analysis presented that the critical point of growth rate occured at two months old, indicated that pre weaning periods is a very important phase. This could also related to the milk production of the does, the longer the milk production can be obtained, the better pre weaning growth will be expected.

Started in 2009, the central government has determined Ettawa goat breeding areas in Banyumas district and request farmers group members to implement the breeding recommendation to improve goat productivity. Kostaman et al. (2020) reported the the performance of Ettawa goat at Banyumas district, with initial owneraship of goat was $4.5+2.07$ and 1.92 +1.2 head, for does and buck, respectively. After joining the program the number of ownership increase significantly, 7.56 \pm 1.23 head and $1.86 \pm 1.29$ head for does and buck, respectively. The number of young female and male was $1.67+1.03$ head and $1.78 \pm 1.3$ head and the number of preweaning kids were 2.2 \pm 1.69 and 2.11 \pm 1.56 , resepctively. This report was encouraging, since farmers increase the number of goat ownership after joining the program, and hopefully it will sustain.

Other breeds of sheep and goats already received Ministry of Agriculture decree of breed registration as well as defined as areas for breed improvement, was also expected to have similar performance. Those breeds can be utilized as genetic improvement according to the traits already defined (Directorate 
General of Livestock and Animal Health, 2016). The implementation of CBP for these districts was conducted through several stages:

1. Deciding which farmer groups should be involved in the program. The project was started with only one farmer group of 20 people, where they received 50 females and 5 males from the government (besides the number of animals they already had). Mating was done naturally in groups of 10 females with one male, weaning was conducted when lambs were 3 months old. Farmers who receive support from the government had to return those offspring at the second year, and those offspring were given to another group.

2. Defining the target production. The target production for the project is a mature body weight at 12 months old, with selection for total weaning weight. However, this is very difficult to achieve since farmers keep all the offspring because they have an obligation to return the offspring. Sometimes farmers need some money and they sell the animals according to the need.

3. Allocating budget for the project. Budget to purchase animals comes from the central government, and usually local/district livestock services are urged to provide supporting funds, as well. Usually the local livestock service provides animal health services. Beside those inputs from the government, farmers provide the in-kind contribution, such as feeding, barn facilities, mating of the females.

The previous example from Argentina as reported by Haile et al. (2014), could be a good reference for
Indonesia, and evaluate how all the infrastructure is needed to make the program work. This case is not yet happening for small ruminant $\mathrm{CBP}$ in Indonesia. However through the simple mechanism as explained above, this model by exploiting male selection is a very important action need to be executed. Best males ever selected can improve the genetic quality of animals at the nucleus level, as well as top females can directly go to the nucleus. Small scale projects have already started; however we need more evaluation, intensive support from research institutes, as well as livestock services, better data collection, data management, data analysis using a defined system, more intense selection process based on data analysis (not only on phenotypic performance) if possible using molecular analysis for the trait being observed, improving genetic structure and flow from the basis population into nucleus and vice versa, and improvement of farmers institution for the activity.

From the figure above, base population depend on animals belong to farmers as the members of the program. Animals registered to the program has to be identified specifically according to year born and the ownership. If the community do not accept castration, unselected males can go to fattening program and be sold after one year old for sacrifice at Idhul Qurban. Besides slaughtering for daily meat consumption, the biggest markets for selling sheep and goats are during Idhul Qurban and aqiqah. A similar challenge was reported by Bhuiyan et al. (2017) in Bangladesh, where the success of CBB was more likely for small ruminants and poultry. It also reported that the biggest challenge in the Buyan study was sustainability of funding and long term commitment of the farmers.

Table 4. Model of Livestock Breeding Design

\begin{tabular}{|c|c|c|}
\hline & Detail & Types of animals \\
\hline \multicolumn{3}{|l|}{ Nucleus breeding scheme } \\
\hline Open nucleus & $\begin{array}{l}\text { Replacement animals for nucleus but also some from base } \\
\text { Selecting from base requires measurement in base } \\
\text { More genetic improvement than closed scheme }\end{array}$ & sheep \\
\hline Close nucleus & $\begin{array}{l}\text { Replacement animals for nucleus only from nucleus Selection } \\
\text { only permanently effective in nucleus. } \\
\text { The nucleus objectives impact on whole scheme. }\end{array}$ & pigs and poultry \\
\hline \multicolumn{3}{|c|}{ Number of tier in the breeding scheme } \\
\hline One tier & Selection, mating, replacement occur within the tier & \\
\hline $\begin{array}{l}\text { Two tier (nucleus - } \\
\text { commercial producers) }\end{array}$ & $\begin{array}{l}\text { Two generation lag occur after the selection process } \\
\text { Breeding rams disseminate directly to commercial producers }\end{array}$ & \\
\hline $\begin{array}{l}\text { Three tier (nucleus- } \\
\text { multiplier-commercial } \\
\text { producers) }\end{array}$ & $\begin{array}{l}\text { Breeding rams from nucleus goes to multiplier and from } \\
\text { multiplier goes to commercial farms }\end{array}$ & \\
\hline \multicolumn{3}{|l|}{ Type of nucleus } \\
\hline Centered nucleus & The nucleus farm is located in one farm & pigs, poultry, some dairy \\
\hline Disperse nucleus & The nucleus farms are located in several areas & sheep, cattle \\
\hline
\end{tabular}

Source: Mueller \& Jones(1984), Nicoll (1990) 
Lesson learn from Marufa et al. (2017) used 380 head of Abera sheep can also worth to adopt for Indonesia situation. The study resulted that lambing interval and age at first lambing were 9.6 and 12.9 months, respectively and expected to be reduced to substantially for a better productivity. Meanwhile, the average litter size, annual reprodution rate and life time lambing were $1.5,1.9$ and 9.5 heads, respectivley, with the mortality rate and twinning rate were $16.8 \%$ and $36.7 \%$, respectively. The production rate of average birth weight, weaning weight and six months weight were $2.8 \mathrm{~kg}, 12.3 \mathrm{~kg}$ and $18.5 \mathrm{~kg}$, respecively. The high lamb mortality indicated that management during pre weaning must be improved significantly to reduce the mortallity rate, which can be contributed from the high percentage of twinning in the flock. Therefore, lambs growth rate either pre weaning or post weaning have to be improved, in order to gain the earlier age at first mating (and age at first lambing as well). Study by Abegaz et al. (2014) reported different scheme of CBP for dairy goats in two different areas of different elevation (Western lowland) and high elevation (Abergelle) in Ethiopia. The selection criterions were based on six months weight, daily milk yield and proportion of kids weaned and the combination among those. The result showed that at Abergelle, the selection intensity and generation interval of 1.99 and 2.88 years were estimated respectively, where as at Western Lowland area the estimated were 2.25 and 2.14 years, respectively. Farmers trait's preferences at three different elevation of sheep farming (low, medium and high land of elevation) conducted in Ethiopia (Neme et al. 2018), were also carefully studied to gain maximum results of the breeding program at the community level. The study showed that farmers prefer to have selection based on male selection, that link directly and indirectly to feeding requirmentsat early age, selection based on body sizes, culling of inferior male animals and will reduce the inbreding level. The common practice in the areas reported that best males were removed for sale, and later on will slowly reduce the genetic quality of the population.

Birhanie et al. (2018) reported Abergelle goat performance through selective breeding in two community breeding based breeding program (CBBP) sites in Ethiopia from 2013-2017 using 1540 progenies for body weight and 291 for milk yield. The result showed that birth weight of progenies selected bucks $(2.3 \pm 0.02 \mathrm{~kg})$ were significantly heavier than the base population $(2.1 \pm 0.02 \mathrm{~kg})$, however the body weight improvement is no longer performed in subsequent growth stages (3, 6 and 9 months weight). Unfortunately, the milk yield improvement from the progeny of the selected bucks $(372 \pm 14.8 \mathrm{ml})$ were not met the expected estimation compared to the base population $(408 \pm 6.72 \mathrm{ml})$. This study revealed that environment has stronger influence than the genetic make up or lack of proper implementation on selective breeding programe.

From the previous study has been conducted and the success story from several countries, it will pursue a better improvement if Indonesia would have to plan, to design and to implement the community breeding program in the future.

\section{SUGGESTION FOR IMPROVEMENT OF THE IMPLEMENTATION OF COMMUNITY BREEDING PROGRAM IN INDONESIA}

With the various CBP implementation practices that have been carried out in Indonesia, the suggestions to improve, include of:

1. Financial sustainability.

Funding is very important in the implementation of this activity, considering that genetic improvement takes a very long time (for example, can be carried out for at least 3 to 5 generations or about 12 - 15 years).

2. Commitment from breeders in implementing CBP.

Farmers who are willing to collaborate in the project, has commitment in the implementation of the breeding objectives and the parameter being measured such as selection, culling, and rearing from the farmers in $\mathrm{CBP}$ activities. Farmers are also requested to have commitment on the animal traits to be improved.

3. Mentoring by academias.

This is a very important aspect in mentoring the implementation of CBP, such things are not happening in long term due to financial support. Besides the involvement of academias from Universities or Research Institute, the farmers instution has to be built as well as active participation of extension service and also key person to the program. Researcher from different expertise such animal breeder, nutritionist, reproductionist, socio economist needed to support the successfull of the program.

4. Data management and analysis.

One of the important keys in evaluating and implementing CBP is the management of data from the farmer level, then analyzed to obtain the breeding value. This figure will become recommendation for maintaining or removing animals from the flock and also to keep the low level of inbreeding. A detail data sheet is required to monitor the data collection and the performance of individuals under the program. The data traffic from farmers to the researcher has 




Figure 1. The Modified open nucleus breeding scheme at IRIAP and IGRI

Notes: Gene flow

to be committed among the players of the program, and data analysis has to be conducted at the frequent basis according to the life cycle of the animals.

5. Economic assessment of superior breeds resulted from the selection in CBP implementation and their uses to improve small ruminant genetic resources. This can be achieved by monitoring the number of animals sold at certain times of the year. The price of superior males was much higher compared to the reguler quality of animals sold as the commercial stocks.

Figure 1 showed the expected breeding scheme probably suitable for farmers in Indonesia, three tier close nucleus breeding scheme could be implemented in the future. The multiplication unit received the rams from nucleus (research institute or livestock breeding centre), where the gene flow moves one direction from nucleus to the multiplication unit and from multiplication unit to the farmers. The multiplication unit can be developed within the research institute or breeding centre and also reside outside and managed by the private sectors. In order to keep the quality of the animals in each level, the best 5\%,10\% and 10\% of rams selected at nucleus, multiplication units and farmers, respectively. Whereas the selection of ewes is expected to be $70 \%, 80 \%$, and $90 \%$ at nucleus, multiplication unit and farmers, respectively. The involvement of private sectors to multiply the new breedstock will accelarate the distribution of the animals. The association of sheep and goats (HPDKI) could play very important roles for their involvement on this breeding scheme either as multiplication unit (on very selected base) or encourage their members to join as commercial farmers. Farmers voluntary to participate this breeding scheme eventually improve the productivity of their animals. However, due to the limited animals holding (ranging from 1-6 heads per farmer), it is suggested that farmers join into group or cooperation. Thus facilitating the monitoring of the production trait, the use of selected rams, data recording, selection and culling of the animals. In Indonesia, very rarely that small ruminant farmers hold a cooperation for meat and milk production. If this model can be implemented and expected to grow, hopefully that the distribution of good quality animal will improve their productivity and directly to the farmers income and welfare.

The experience of Ethiopia (Haile et al. 2019) to a success and sustainability of CBP implementation require long term investment both from public and private. A similar responses was also reported by Sheriff and Alemayehu (2018) in which they reported that expected genetic improvement did not happen as desired genetic improvement. Therefore a data analysis is very important in order to avoid such shortages. Report from Kostaman et al. (2020) indicated that farmers who are willing to join the program, benefits from the increase number of goat ownership during the program. However the calculation of animal genetic value did not occur to animals involve in the program. This genetic analysis need to be improved in the future, if Indonesia would like to implement the successful CBP.

\section{CONCLUSION}

It can be concluded that community breeding programs for sheep and or goats can be implemented in Indonesia, with special attention to a) farmers commitment to be actively involved, b) breeding objectives of the selected breed c) active support from the government, academia and private sectors. For the genetic improvement programs that have already been started in Indonesia, progress can be accelerated through long term funding support, better recording of the data, more support from the research centres and improvement of farmers institutions. 


\section{REFERENCES}

Anggraeni A. 2018. Pengaruh lingkungan dan genetik tetua pada pertumbuhan anak kambing sapera. Dalam: Muchlis et al, penyunting. Inovasi Teknologi Peternakan Menyongsong Era Industri 4.0. Prosiding Simposium Nasional Penelitian dan Pengembangan Peternakan Tropik. Yogyakarta, 5 November 2018. Yogyakarta (Indonesia): Universitas Gadjah Mada. hlm. 177-182.

Anggraeni A, Saputra F, Kumalawati DS, Sumantri C. 2020. Effect of litter size, kidding age, mating weight, and kidding weight on partial cumulative milk yields in G1 Sapera goat. IOP Conf Ser Earth Environ Sci. 492:012107. doi: 10.1088/1755-1315/492/1/012107.

Adhianto K, Sulastri S, Iqbal Hamdani MD, Novriani D, Yuliani L. 2017. Performans kambing saburai betina di wilayah sumber bibit Tanggamus Provinsi Lampung. Jurnal Ilmu-ilmu Peternakan. 20:9-16.

Adhianto K, Iqbal Hamdani MD, Sulastri S, Listiana I. 2016. Performan produksi kambing saburai jantan pada dua wilayah sumber bibit di Kabupaten Tanggamus. Sains Peternakan. 14:22-29.

Adhianto K, Iqbal Hamdani MD, Sulastri S. 2015. Model kurva pertumbuhan pra sapih kambing saburai di Kabupaten Tanggamus. Jurnal Sain Peternakan Indonesia. 10:95-100

Abegaz S, Solkner J, Gizaw S, Dessie T, Haile A, Mirkena T, Getachew T, Wurzinger M. 2014. Optimizing alternative schemes of community-based breeding programs for two Ethiopian goat breeds. Acta Agraria Kaposvariensis. 18:47-55.

Bhuiyan MSA. Bhuiyan AKFH, Lee JH, Lee SH. 2017. Community based livestock breeding programs in Bangladesh: present status and challenges. J Anim Breed Genom. 1:77-84. doi: 10.12972/jabng. 20170009.

Birhanie M, Alemayehu K, Mekuriaw G. 2018. Performance evaluation of Abergelle Goat under community based breeding program in selected districts, Northern Ethiopia. Livest Res Rur Dev. 30:4.

Dagnew Y, Urge M, Tadesse Y, Gizaw S. 2018. Conservation based breeding program design for genetic improvement in Gumz sheep in the Western lowlands of Ethiopia. Agric Food Secur. 7:34.

Destomo A, Febresiana A, Sinulingga SE. 2018. Physiological response, productivity and behavior of Boerka's goat on different grazing time. In: Wina $\mathrm{E}$ et al, editors. Smart Livestock Management to Support Breeding Stock Availability toward Modern Agriculture. Proceeding of International Seminar on Livestock Production and Veterinary Technology. Kualanamu, 16-17th October 2018. Jakarta (Indonesia): IAARD Press. p. 153-163. doi: 10.14334/Proc.Intsem.LPVT-2018-p.153-163.

Directorate General of Livestock and Animal Health. 2016. Decree of Directorate General of Livestock and
Animal Health. Number: 618/KPTS/PK.230/F/03/201. Jakarta (Indonesia); Directorate General of Livestock and Animal Health, Ministry of Agriculture.

Directorate General of Livestock and Animal Health, 2019. Livestock and Animal Health Statistics. Jakarta (Indonesia); Directorate General of Livestock and Animal Health, Ministry of Agriculture.

Dossa LH, Sangare M, Buerkert A, Schiecht S. 2015. Production objectives and breeding practices of irban goat and sheep keepers in West African: regional analysis and implicatios for the development of supportive breeding programs. Springer Plus. 4:281.

Duguma D, Mirkena T, Haile A, Okeyo AM, Tibbo M, Rischkowsky B, Solkner J, Wurzinger M. 2011. Identification of smallholder farmers and pastoralists preferences for sheep breeding traits: Choice model approach. Animal. 5:1984-1992.

Granleese T, Clark SA, Swan AA, van der Werf J. 2015. Increased genetic gains in sheep, beef and dairy breeding programs from using female reproductive technologies combined with optimal contribution selection and genomic breeding values. Genet Sel Evol. 47:70. doi: 10.1186/212711-015-0151-3.

Haile A, Gizaw S, Getachew T, Mueller JP, Amer P, Rekik M.and Rischkowsky B. 2019. Communitybased breeding programmes are a viable solution for Ethiopian small ruminant genetic improvement but require public and private investments $\mathbf{J}$ Anim Breed Genet. 136:319-328. doi: 10.1111/jbg.12401.

Haile A, Dessie T, Rischkowsky B. 2014. Performance of indigenous sheep breeds managed under community based breeding programs in the highlands of Ethiopia: Preliminary results. Addis Ababa: ICARDA. hdl.handle.net/10568/35466.

Haile A, Wurzinger M, Mueller J, Mirkena T, Duguma G, Mwai O, Sölkner J, Rischkowsky B. 2011. Guidelines for setting up community-based sheep breeding program in Ethiopia. ICARDA - tools and guidelines No.1. Aleppo, Syria, ICARDA.

Ginting SP, Simanihuruk K, Tarigan A, Pond KR. 2018. Nutritional support for small ruminant development based on oil palm by-products. Wartazoa. 28:189198

Kostaman T, Hapsari AAR, Setiawan S, Tiesnamurti B, Anggraeni A. 2020. PE goat performance in the breed stock area, Banjarmangu sub-district, Banjarnegara District, Central Java Province. Proceeding of Japan ASEAN Science Technology and Innovation Platform Symposium. Serpong 23-26 Oktober 2019 (in-press).

König EZ, Mirkena T, Strandberg E, Audho J, Ojango J, Malmfors B., Mwai Okeyo A, Philipsson J. 2016. Participatory definition of breeding objectives for sheep breeds under pastoral systems the case of Red Maasai and Dorper sheep in Kenya. Trop Anim Health Prod. 48:9-20. 
Lacerdaa TSA, Caetano AR, Facó O, Assis de Faria D, McManus CM, Lôbo RN, de Moraes Silva K, Paiva SR. 2016. Single marker assisted selection in Brazilian morada nova hair sheep community-based breeding program. Small Rumin Res. 139:15-19.

Lamuno D, Solkner J, Meszaros G, Nakimbugwe H, Mulindwa H, Nandolo W, Gondwe T, van Tassel C, Guttierez G, Wurzinger M. 2018. Evaluation framework of community-based livestock breeding programs. Livest Res Rur Dev. 30:1-12.

Marufa E, Taye M, Abebe G, Tera A, Jimma A. 2017. Effect of non genetic factors on reproductive and growth performance of abera sheep under community based breeding program in SNNPRS. J Adv Dairy Res. 5:4. doi: 10.4172/2329-888X.1000196.

Mrode R, Tarekegn GM, Mwacharo JM, Djikeng A. 2018. Invited review: genomic selection for small ruminants in developed countries: how applicable for the test of the world?. Animal. 12:1333-1340.

Mohammed T, Kebede K, Mekasha Y, Abera B. 2014. Herd management and breeding practices of sheep owners in North Wollo Zone, Northern Ethiopia. Middle-East J Sci Res. 21:1570-1578.

Mueller JP, James JW. 1984. Developments in open nucleus breeding systems. inta bariloche, comunicación técnica PA Nro. 175. Hofmeyer J, Meyer E, editores. Trabajo presentado al Segundo Congreso Mundial de Ovinos y Bovinos de Carne, Pretoria, Sudáfrica, 1619 abril de 1984 y publicado en los correspondientes. Proceedings. pag. 204-213.

Neme Y, Kirmani MA, Duguma G. 2018. Farmers' trait preferences for breeding of small ruminants in Ada Barga and Ejere Districts of West Shoa Zone, Oromia, Ethiopia. Int J Livest Res. 8:49-61.

Nicoll GB. 1990. Application of Nucleus Breeding Schemes in a Corporate Setting: Sheep, Beef Cattle and Deer. Beef Cattle, Sheep and Pig Genetics and Breeding, Fibre, Fur and Meat Quality. Proceedings of the 4th World Congress on Genetics applied to Livestock Production. Edinburgh 23-27 July 1990. p. 357-360.
Priyanto D, Suradisastra K. 2018. Nurturing sheep hamlet of Cinyurup: a paralel to SR CRSP field experience: an insight of sheep hamlet, Cinyurupan Juhut, Province of Banten. In: Wina E et al, editors. Smart Livestock Management to Support Breeding Stock Availability toward Modern Agriculture. Proceeding of International Seminar on Livestock Production and Veterinary Technology. Kualanamu, 16-17th October 2018. Jakarta (Indonesia): IAARD Press. p. 379-388. doi: 10.14334/Proc.Intsem.LPVT-2018-p.379-388.

Santos BFS, van der Werf JHJ, Gibson JP, Byrne TJ, Amer PR. 2017. Genetic and economic benefits of selection based on performance recording and genotyping in lower tiers of multi-tiered sheep breeding schemes. Genet Sel Evol. 49:10.

Sheriff O, Alemayehu K. 2018. Small ruminant production systems and breeding programs in Ethiopia: achievements, challenges and lesson learned: A Review. Online J Anim Feed Res. 8:59-73.

Simanihuruk K, Chaniago A, Sirait J. 2013. Penggunaan ampas sagu sebagai campuran pakan komplit kambing boerka fase pertumbuhan. In: Purwantari et al, editors. Inovasi Teknologi Peternakan dan Veteriner Berbasis Sumber Daya Lokal yang Adaptif dan Mitigatif terhadap Perubahan Iklim. Prosiding Seminar Nasional Teknologi Peternakan dan Veteriner. Medan, 3-5 September 2013. Bogor (Indonesia): ICARD. p. 373-381.

Tarigan A, Ginting SP, Arief II, Astuti DA, Abdullah L. 2018. Body weight gain, nutrients degradability and fermentation rumen characteristics of boerka goat supplemented green concentrate pellets (GCP) based on Indigofera zollingeriana. Pak J Biol Sci. 21:87-94. doi: 10.3923/pjbs.2018.87.94.

Wurzinger M, Escareño L, Pastor F. Salinas H, Iñiguez L, Sölkner J. 2013. Design and implementation of a community-based breeding program for dairy goats in Northern Mexico. Trop Subtrop Agroecosys. 16:289296. 